\title{
Reseña
}

\section{Gledhill, John. 2015. The new war on the poor. The production of insecurity in Latin America. Londres: Zed Books.}

\begin{abstract}
Alke Jenss $^{1}$
Fecha de recepción: 31 de enero de 2017

Fecha de aceptación: 31 de enero de 2017
\end{abstract}

$\mathrm{S}$ ecurity is a topic often dominated by strategic military studies or think tanks with a decidedly positive stance on states' function to provide order for businesses and citizens. But how is 'security' defined, and who actually benefits from states' measures to provide it? Who is targeted as a threat to this particular definition of security? Anthropologist John Gledhill in "The New War on the Poor" provides an illuminating perspective on state measures towards parts of society which are defined as a threat to the dominant social order -- while on the other end of the spectrum are those parts of society actually enjoying citizen rights and sharing the state's definition of security. Gledhill's cases are Mexico and Brazil, two formally democratic countries illustrative for the entanglement of politics of power, militarized policing and economic policies which as a conjunction lead to what Gledhill terms "the production of insecurity".

Gledhill argues the 'co-production' of insecurity by various violent actors -- state institutions as well as those perceived as criminal actors -- is widespread, and he goes on to show this in urban as well as rural contexts. It is this multiplicity of actors of violence which makes the lives of many in those countries a volatile affair. But he takes this argument further: He sees the politics of policing in Mexico or Brazil as an outright war on the poor which not only makes them prone to be victims of violence of either state representatives or of criminal groups, but also deflates their economic perspectives. Gledhill analytically links the war on crime to accumulation by dispossession. Those who hinder accumulation processes or are "potentially threatening to the power relations the state seeks to maintain or expand"(p. 3) are discursively and factually turned into threats to society, even if these developments are not without resistance and contradictions.

In the introduction Gledhill puts his approach into perspective. He distuingishes his work from securitization approaches; his focus are the consequences of the security discourse in the two countries studied, not discourse itself, and the different ways in which security and development have been linked

1- Nacionalidad: Alemana. Grado: Doctorado. Especialización: Gestión de conflictos. Adscripción: Universidad de Bielefeld. Correo electrónico: alke.jenss@uni-bielefeld.de 
in social sciences. His criticism of the tendencies to locate the causes for violence solely within the global south itself (as in the World Bank Development Report 2011) goes hand in hand with a broader stance on the relation between capitalism and insecurity of lives on the margins precisely because of their involvement in the capitalist economy, be it in the form of violent appropriation of land by criminal actors or the opening up of their barrios to electricity or water providing companies.

Chapter two and three deal with Brazil as a case and first focus on the two megacities Sao Paulo and Rio before turning to special police forces UPP based on Gledhill's own field work in Bahia. Chapter four and five are concerned with Mexico. After a general introduction in chapter four analgous to Brazil, chapter five is based on Gledhill's own ethnographic field work in Michoacán which refers to some thirty years of research experience in that part of Mexico. Michoacán is a particularly interesting case and Gledhill's experience particularly valuable because the state has seen some of the most violent incidents in the so-called "war on drugs" and with the seemingly autonomous but difficult to define "autodefensas" or self-defence-movements presents a phenomenon that has drawn attention from the media and scholars alike. Gledhill's conclusion in Chapter six goes far beyond a simple resumee of the preceding chapters.

Obviously developments are not identical in the two countries under study, and instead, recent differ a lot. Mexico has, since the 1980s debt crisis and the signing of NAFTA free trade agreement in 1994 continually opened towards investment and recently even opened its oil sector to broad foreign investment, formerly a holy cow of Mexican nationalism. Labour laws were "flexibilized", the change of community lands into private property facilitated and ecological regulation has been sadly absent from Mexican economy. The still numerous rural population in Mexico is desperately turning to cities, adding to existing marginalized barrios and the informal sector, but most of all to the social base of a violent transit economy of drugs.

Contrary to that, until the downturn of Dilma Rousseffs government since 2014 Brasil had put on tighter capital controls and introduced new regulation of firms and investors and was able to enforce poverty reduction programmes such as 'zero hunger'. Social mobility was again an upward possibility. The rise of rightwing forces has, however, been preceded by anti-crime politics corresponding with U.S. American right wing ideas such as Giuliani's. These don't differ as much from the militarized, bodycounting anti-crime politics in Mexico framed as the 'war on drugs'. Gledhill names this brazilian paradox and traces differences and similiarities between the two countries with impressive clarity. He avoids to isolate "crime" from the rest of social relations and so-called anti-crime measures from the overall socio-economic model pursued. Gledhill's ethnographic work is not restricted to the descriptive but carves out the contradictions inherent to the capitalist system, while unpacking what is often presented "naturally" as cause and consequence (pp. 9ff.).

Explanations are not to be simplified. No doubt population in both countries perceives serious security problems. Gledhill however, questions the militarized formula of policing which has dominated favela pacification in Rio or anti-drug measures in Mexico.

While actual early community policing programmes had been a success, they were abandoned towards a more militarized, but „intelligent“ model: police special forces UPP were supposed to „pacify“ favelas in the forefront of the 2014 World Cup. The UPP model, following Gledhill, „reinforced a „securitization of social disadvantage, with racialized undertones" (p. 49), while the improvement of citizens ' rights 
within the UPP concept usually fell short of expectations. UPP in Sao Paulo now share the streets with militias and drug traffickers, while, it seems, the favela citizen is constructed as an enemy.

Gledhill's findings in Bahia are based on interviews with residents and participation in community organization meetings. He tells stories of disappearances, torture and abuse, and a general feeling of being „between a rock and a hard place“ (p. 73) as neither state representatives nor hegemonic criminal groups provide a reliable environment in which to make a living not dominated by fear. Ultimately, „since power relations based on class and racial hierarchies continue to dominate", even police officers who are originally from poor neighbourhoods, „often end up acting as instruments for the defence and reproduction of those hierarchies in their everyday practice“ as they try to validate themselves as being „more than just another poor person from the urban periphery“ (p. 69). In the overall imaginary in society thus, they contribute to constructing poverty as „black“ and crime as belonging to the favelas where the most visible outcomes of criminal activity are perceived (p. 69).

Gledhill's interviews with policewomen and men from Calabar, a part of Bahia where proximity policing had actually been a success, are particularly interesting. Some not only stress their frustration at the bad image police enjoys in the bairros, but also mention bad quality of training or machista culture in the force. They are not uncritical of policing measures, but are determined on their own possibilities of social mobility upwards. Yet, the „paternalistic and authoritarian ethos“ (p. 69) still generalized in the police force is reminiscent of the role they had during the military dictatorship.

What is revealing are Gledhill's recounts how once and again it becomes publicly known how criminal organizations have ties beyond crime, how their networks involve politicians and vice versa. They are structural in that there is a long-term relation, but flexible in that actors, groups and names are continually modified.

Gledhill's chapters on Brazilian cities illustrate that within this security policy, the dispossession of many turns into the capital accumulation of some (p. 61f.). While the granting of private property titles together with ,pacification' lead to favelas being too expensive for favelados themselves, electricity providers and other firms can claim the marginalized barrios as their recently opened up markets. Favela dwellers pay surprisingly high additional expenses and life in favelas is generally becoming more expensive, while Gledhill criticizes that improvement of infrastructure, health services or schooling is still much less a priority than the costs of police personal, maintenance of police posts and equipment. Favelas serve as 'new' spaces to be opened up to accumulation. Gledhill shows that the poor neighbourhoods in Bahia, Rio or Sao Paulo are not exactly marginal to capital accumulation in the neoliberal stage, but rarely enjoy the same safe spaces or rights to plan their community's development as middle classes.

In Mexico, Gledhill identifies social forces dominating decisions about security strategies, namely the entrepreneurial society. Historically Michoacán is one of the states in Mexico where haciendas, with the monopoly on commercially exploitable land and their own private army to underpin a labour-repressive regime, persisted after the land reforms of post-revolutionary days.

Gledhill recounts how parts of Michoacán society based their class-stratified social order on private property relations and despised those who, in the post-revolutionary Ejido system, had received land from the state which was unalienable. While the hegemony of the central state party PRI was not established against sub-regional cacique-style rule, it was indeed state-led investment in infrastructure which facilitated the geographic expansion of the drug economy towards a more integrated network of trade 
and transit routes. The consequences of structural adjustment during the 1980s led to an even closer mingling of legal and illegal enterprise (investment possibilities in the illegal sphere).

Gledhill's differentiation between different armed groups is important: His field of study here is indigenous community policing which is recognized by the Mexican constitution and by ILO standards on indigenous autonomy. In the municipality of Ostula communal police were established to protect the community against paramilitary gunmen, but also served as the community's backup, especially when invading a strip of land in 2009 which supposedly had been usurped by mestizo landowners. In fact, the Ostula story illustrates Gledhill's main argument: Disputes over land and in consequence, valorization and the possibility of capital accumulation are again at the core when considering policing strategies in these Mexican communities.

Legal recognition for the invasion or for the community force was ultimately denied, and the Mexican Marines disarmed the community police, "setting in train a series of killings [...] that robbed the community of its principal leaders and activists" (p. 178). The gunmen responsible for the deaths, who Gledhill can plausibly identify as being involved in the marijuana trade, enjoy impunity. A convergence of state and private interests (impeding the invasion of land and establishment of new autonomous settlement by an indigenous community) spurred violence and insecurity: "The indigenous communities in general, and Ostula in particular, as the most militant of them, had become an impediment to various twenty-first century projects for making the coastal region contribute more to processes of capital accumulation" (p. 179), hindering the development of beaches, eco-tourism in the sierra, and the Pacific Highway as part of a state tourism development plan. Above all are interests for mining, in legal as well as illegal form.

In contrast to indigenous police, newly established "autodefensas" in Michoacán do not have the same quest for autonomy, but often received financial support from farmers or businessmen and were later partly recognized by the military as "rural defence forces". Differentiating them from indigenous police, Gledhill shows how state representatives rather administered the continuity of violence and exercise of local power (p. 194): They turned a blind eye to the appropriation of property as long as property relations stayed the same, while their readiness to intervene against community police such as in Ostula is at least surprising. Gledhill is really one of the first to dissect these constellations for an English reading audience, relating the more detailed security issues to a broader understanding of a state concerned with maintaining property relations, facilitating accumulation processes on a local level and linking them to demands of a global economy.

Gledhill's book is not only a well-written, detailed analysis of insecurity in two major countries of Latin America, but can be read as a call to action. Activists can rely on his analysis to call on governments to end mutual police-exchanges and support of those structures.

"[T] he centrality of accumulation by dispossession in contemporary capitalism" (p. 198) involves speculation processes as dispossession is linked to financialization while there are obvious differences between favela dwellings being drawn into accumulation circuits such as in Brazil and rural contexts where accumulation is based on open pit mining such as in Mexico. In both contexts, securitization becomes a means of securing accumulation, and the politics of producing insecurity for some in localities in Mexico or Brazil are part and parcel of global capitalist development. This way, measures such as the settlement of investment disputes is not to be understood entirely separately from crime politics as economic perspectives are rare in the export-oriented economy dominated by mining and large-scale agricultural industry of many Latin American countries. 
- Revista de Ciencias Sociales y Humanidades. ISSN-P: 0188-9834 ISSN-E:2395-8669.

The consequence of missing economic perspectives, social services and social mobility are emigration, a social base for criminal groups and a thriving, equally export oriented illegal economy. Gledhill is careful not to assume homogeneous interests for this kind of insecurity but stresses complexity and contradictions. We can deduct from his study that the multiplicity of actors of violence is not entirely dysfunctional to the state, but makes a deployment of force seem reasonable at least to considerable parts of society. In fact, the co-production of insecurity serves to blur the picture and sometimes leads to demands for even more militaristic responses. Gledhill's analysis illuminates these complex linkages and enables us to understand the place of class and race, violence and repression, the state and non-state actors within this conglomerate of factors that shape the lives of a marginalized yet integral part of society. 